\title{
An appropriation of Psalm 82 against the background of the Fourth Industrial Revolution. The Christian church as a change agent in the Fourth Industrial Revolution
}

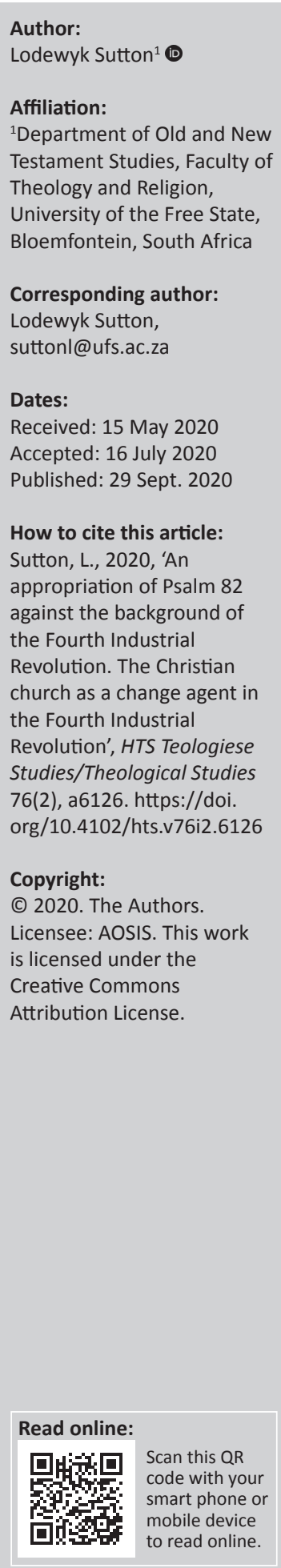

In an era during which more and more people show signs of narcissism, extreme individualistic views and a lack of empathy for others, the evidence that a definite change in society has taken place cannot be denied. This change is, in many ways, the result of the fast-growing pace of development and availability of technology, also known as the Fourth Industrial Revolution, in terms of which change has become a daily occurrence. Accessibility to the Internet and social media platforms contributes to the rapid change in society and how people and specifically younger generations view themselves and approach others. Amid this change, the church must act as a positive change agent and should not oppose change. Change has become a constant in the Fourth Industrial Revolution, and the church thus needs to become an agent in this process of change, to reorientate the focus of society and overcome the self-centeredness induced by current technological progress in society. What should such a focus look like? In answering this question, perspectives from Psalm 82 and the Old Testament are considered.

Contribution: This article makes an interdisciplinary contribution, drawing knowledge from the Psalms in the Old Testament, social anthropology and technological advancement studies as to contribute on the relevance of theology today and the importance of understanding generational differences in a time of technological growth and the Fourth Industrial Revolution.

Keywords: Fourth Industrial Revolution; Authority; Change agent; Collectivistic; Generation Me; Group orientation; Individualism; Narcissism; Poor; Psalm 82.

\section{Introduction}

In an era during which more and more people show signs of narcissism, extreme individualistic views and a lack of empathy for others, the evidence that a definite change in society has taken place cannot be denied. This change is, in many ways, the result of the fast-growing pace of development and the availability of technology, also known as the Fourth Industrial Revolution, in terms of which change has become a daily occurrence. Accessibility to the Internet and social media platforms contributes to the rapid change in society and how people view themselves and approach others. Semioticians such as Leonard Sweet have produced multiple publications such as Viral: How Social Networking Is Poised to Ignite Revival (Sweet 2012) and From Tablet to Table (Sweet 2014) that indicate the importance of the impact that the Internet and social media have on people and for the church. ${ }^{1}$ The church must now more than ever be able to understand its own context and be able to become a semiotician of its time.

In the midst of this change, the church must act as a positive change agent and should not oppose change. Many industries and personal development groups have realised the importance of change management as a critical factor for success. The impact of this realisation is seen in popular publications such as Who Moved My Cheese? (Johnson 2002), Our Iceberg Is Melting (Kotter \& Rathgeber 2006) and The Power of Habit: Why We Do What We Do and How To Change (Duhigg 2013). Unfortunately, it seems that this is a difficult task for the church. Research publications from the Barna Group, such as Unchristian: What a New Generation Really Thinks about Christianity ... And Why It Matters by David Kinnaman and Gabe Lyons (2007) and also Good Faith: Being Christian When Society Thinks You're Irrelevant and Extreme (Kinnaman \& Lyons 2016), indicate the

1.The use of the term "church" in this article must be viewed as a collective term for the institution of the church, but also each individual person representing the body of Christ, unless specifically stated.

Note: Special Collection entitled Christianity as a Change Agent in the 4th Industrial Revolution World, sub-edited by Erna Oliver (UNISA) 
difficulty for the church to be viewed as relevant and important. Change has become a constant in the Fourth Industrial Revolution, and the church thus needs to become an agent in this process of change, to reorientate the focus of society and overcome the self-centeredness induced by current technological progress in society. What should such a focus look like?

To answer this question, an overview of the Fourth Industrial Revolution is firstly presented. Secondly, Generation Me and the question of individual or group-orientated societies are discussed. Thirdly, perspectives from Psalm 82 and the Old Testament are considered. Lastly, all of the above findings are appropriated to the question of how the church can be an effective change agent in the Fourth Industrial Revolution.

\section{Fourth Industrial Revolution and narcissism}

Klaus Schwab (2016:11) writes that the core meaning of the word 'revolution' is the element of change. Throughout history, new developments, technology or new and original ways have changed the way things are done and have changed 'economic systems and social structures'. Abrupt and rapid change is one of the central characteristics of the Fourth Industrial Revolution. Schwab (2016:11) explains that the First Industrial Revolution took place around 1760-1840 CE, with the invention of the steam train. The Second Industrial Revolution started in the late 19th century and continued into the early 20th century. This revolution was triggered by the invention of electricity and the assembly line that introduced mass production. The Third Industrial Revolution began in the 1960s, with the invention of computers. This revolution was also called the 'digital revolution'. It was during this period that the Internet was established. The Fourth Industrial Revolution started just before and at the turn of the millennium, the year 2000. This revolution is a higher and more developed context of the digital revolution and is also called 'Industry 4.0 ' by some (Schwab 2016:11-12). The development that is taking place because of advanced computers and/or digital technologies reaches not only networking and physical computers but also almost all of the other sectors of development. Schwab (2016:19-26) divides the trends that drive this development of digital power into three groups: physical (autonomous vehicles, threedimensional printing, advanced robotics, new materials); digital (development of the Internet); and biological (genetics, synthetic biology). These groupings mention but a few of the new developments possible because of the technologies developed in the Fourth Industrial Revolution. ${ }^{2}$

Sweet $(2019: 141)$ states that in this period of the Fourth Industrial Revolution 'anything that can be digital, will be' digital. He maintains that this revolution brings together 'digital, biological, smart networks, delivery drones, world

2.The need to understand and guide people in this Fourth Industrial Revolution is apparent in publications such as those of Gleason (ed. 2018) and Kelly (2019). apparent in publications such as those According to 2020, the total world population is 7.75 billion. Of these 7.75 billion people, there are 5.19 billion unique mobile phone users, 4.54 billion Internet users and 3.80 billion active social media users around the globe. brain, augmented reality and GRAIN'. GRAIN, according to Sweet (2019:141), stands for genetic engineering, robotics, artificial intelligence, information technology, and nanotechnology. For him, the most prominent warning of the Fourth Industrial Revolution is that technologies named in GRAIN could easily fall 'between the cracks of morality'. The more these technologies grow, the more power is seated in the individual 'I'. He states that 'in a highly connected world, we suffer from the misdeeds of a few as much as we benefit from generous actions and affections of the many' (Sweet 2019:141). It is this connectedness that brings this individual ' $\mathrm{I}$ ' of the Fourth Industrial Revolution to light. Scott Galloway (2017:1) calls the four most prominent companies that connect people and things on the Internet the 'four horsemen', namely, Amazon, Apple, Facebook and Google. Of course, there are more examples, for instance, Instagram, Twitter, YouTube and many more. ${ }^{3}$ What is troublesome is that research is indicating a relation between the digital revolution, specifically the Internet with all of the social platforms, and narcissism. ${ }^{4}$ The self-obsessive ' $\mathrm{I}$ ' is even further developed in the digital age. ${ }^{5}$

For the church to be an effective change agent in the Fourth Industrial Revolution, it needs to learn first of all how to embrace change, as this is a given for this age. Secondly, the impact of the digital age on industry and societies in this revolution is extreme. Thirdly, one of the negative factors of the digital age is that it sustains an individual society that can lead to extreme forms of self-obsessiveness and even narcissism. The church, therefore, needs to be familiar with the generation that functions primarily in this Fourth Industrial Revolution and with how this society ${ }^{6}$ differs from ancient biblical societies.

\section{Individualism or group orientation?}

Jean Twenge (2014:1) writes about 'Generation Me' (GenMe), so called because they are the under-35 young people who were born in a time that is all about me, myself and I (see also Elias [2001:155-237], on the 'We' to 'I' change that took place). Homo sapiens are on their way to becoming Homo Deus, as Yuval Harari (2015) describes in his book Homo Deus: A Brief History of Tomorrow. This is a generation that was born after the cultural mainstream of self-focus ${ }^{8}$ was already established and therefore they are a generation that is not familiar with a

3.Sweet (2019:155) indicates that in the Fourth Industrial Revolution, societies are individual and inward-orientated and that 'the four' strengthen this individual and selfish behaviour. He describes 'the four' in these terms: selfish behaviour. He describes 'the four' in then appeals to our hunger for things.
- Amazon

- Google appeals to our hunger for knowledge.

- Google appeals to our hunger for knowledge.

- Apple appeals to our hunger for beauty (and sex).

4.On the topic of narcissism, see Lasch (1991).

5.For further discussion and research on the relation between the Internet, socia platforms and narcissism, see: Ryan, Bednar and Sweeder (1999:115-128), Leung (2013:997-1006), Alloway et al. 2014:150-158), Davenport et al. (2014:212-220), Reid and Thomas (2017:40-56) and McCain and Campbell (2018:308-327).

6.One should be careful not to talk only of a society; it should rather be understood as societies.

7.Also called Gen Y or millennials, typically those born between 1983 and 1994 (Twenge 2014:5).

8.It is important to understand that being born at a specific time is not a rigid definition of a specific person or group, but must rather be understood as a definition of the culture a person has absorbed or is influenced by (Twenge 2014:6). 
world that would put duty before the self (Twenge 2014:1). This is the quintessential Fourth Industrial Revolution generation. What makes this generation different from most of the previous generations (or groups) is that from birth they are taught to put themselves first. Therefore, the individual ' $\mathrm{I}$ ' is at the centre: it is not about the interests of a social group. Furthermore, because of this mentality of extreme self-confidence, ${ }^{9}$ their individualism is strengthened. The difference is that the previous generation was focused on introspection and self-absorption, while this GenMe is 'not as much self-absorbed as self-important' (Twenge 2014:8).

Another significant difference from other generations is that where personal goals or dreams are not valued as much as social expectations by previous generations, this generation places high value on personal goals or dreams, strengthening their individualistic viewpoint rather than a selfish one (Twenge 2014:8). For GenMe the rule would be to 'just be yourself', meaning that for them the individual determines what is best or 'cool' and not the group. It is socially more acceptable to be 'independent' and 'open-minded' (Twenge 2014:29). When it comes to moral views and social norms, GenMe is of the opinion that each person is responsible for his or her own way of thinking and personal opinion, and therefore one may not question others' views. There is therefore 'no moral reasoning outside of themselves'. Twenge (2014) writes about an interview with a GenMe person:

When asked if people have any moral responsibility or duty to help others, one young person replied, 'No, not really'. Would it be a problem if someone didn't want to help others? Asked the interviewer. 'No ... They can help themselves ... Do they really need anyone else?' he replied. 'So if someone asks for help, we don't have an obligation to them?' prodded the interviewer. 'Yeah, it's up to each individual. Of course', the young adult asserted. (p. 20) ${ }^{10}$

According to Twenge (2014:43), GenMe in American history is the least religious generation because of the fact that most of them are being raised by non-religious parents, and also as young adults they are leaving religion because of low interest. For those who do follow a religion, it is viewed rather as 'therapeutic individualism', focused on subjective feeling and self-improvement (Twenge 2014:45). All this being said, it seems that although GenMe individuals have high self-esteem, are free and equal to all, and want to follow their dreams, they are also the generation with the most depression, are very cynical and are anxious about how to achieve their dreams (Twenge 2014:283-284). Twenge (2014:284-290) is of the opinion that the self-esteem movement for raising GenMe failed and created 'little narcissists' and should change for the sake of the upbringing

9.This extreme self-confidence is seen in the recent world pandemic of coronavirus disease 2019 (COVID-19), also known as severe acute respiratory syndrome coronavirus 2 or SARS-CoV-2 (National Institute for Communicable Diseases 2020), where it is reported that millennials are not taking COVID-19 seriously. Amy Gunia (2020) reports that a millennial said to her that ' $[i] \mathrm{f}$ I get Corona, I get Corona' and ' $[a] t$ the end of the day, I am not going to let it stop me from partying ... We've been waiting for Miami spring break for a while' (cf. also Stieg 2020).

10.In an article about the differences on how millennials and boomers (those born between 1944 and 1964) handle the COVID-19 pandemic, the lack of empathy by millennials is noted. This lack of empathy demonstrates the high self-esteem and self-absorbed focus (narcissistic view) of millennials, who act as if they are immune self-absorbed focus (narcissistic view) of millennials, who act as if they are immune
to the virus. The article references social media memes (by millennials) calling to the virus. The article references social media
COVID-19 the 'boomer remover' (Foroohar 2020). of following generations. What is essential, then, is moving away from the individualistic self-esteem view (maybe narcissism) to a self-efficacy and community focus.

If the church wants to be an effective change agent for this time and generation, then it needs to understand the focus of GenMe. This is a generation with an extremely high individual self-focus and self-esteem, which is personal dream orientated and places a high value on personal opinion. Religion is viewed as extremely private and individualistic, therefore inward orientated and focused on self-improvement. Unfortunately, because of these traits, GenMe individuals are prone to depression, as they do not know how to reach their goals and are overly cynical.

How then, in the ancient Near Eastern and Mediterranean contexts, does the understanding of individualism differ from that of GenMe? The principal difference is that this view of individualism did not exist in the ancient Near East; instead, the individual's focus was 'collectivistic', or grouporientated. How they viewed themselves was determined by other people or by their dyad, ${ }^{11}$ meaning that they were 'other-orientated' people (Pilch 2016:20-21). How is the 'self' or 'individualist self' then understood in a collectivist culture? According to Pilch (2016:22), anthropologists divide the self into three selves, namely, the private self, the public self and the collective or the in-group self. The private self is how a person sees himself or herself: his or her own traits and behaviours. The public self is how a group defines a person (their expectation of a person): all those you have interaction with on a regular basis. The collective self is what your ingroup says about you (their expectation of a person): your family and friends. In all three definitions, what I think of myself is always important within the collectivistic context; what I think of myself, but also what I think others think of me. Within a collectivistic culture the relations between the private self and the collective self are dependent on each other. What my in-group says about me is how I would view myself or rather my private self. Feedback from a person's in-group is viewed as extremely important, as it helps a person to be part of the in-group. An individual's opinion that is expressed is therefore done in relation to what the ingroup wants or says (Pilch 2016:23; cf. Malina 2010:17-28). Therefore, in a collectivistic culture, what the individual thinks privately is not what he or she will say, as his or her own opinion is not valued. In contrast, for GenMe, personal opinion and not that of the group is important: the personal opinion of each individual must be recognised.

When it comes to a topic such as truth for a collectivistic culture, the in-group's view on a subject is the truth for that

11.In ancient Near Eastern and Mediterranean cultures, people were not valued for their individualism or uniqueness, but rather according to which in-group or dyad they belonged. This relationship to the dyad was understood in terms of place (where you came from), nation (to which nation you belonged), clan (for example to which tribe of Israel you belonged) and family (who your family was). Individual people were known through their dyad, and therefore a person's honour (the in group, clan or nation) could be checked, affirmed or challenged by another person (in-group, clan or nation). The result of these associations with your in-group, clan (in-group, clan or nation). The result of these associations with your in-group, clan or nation was that these cultures were highly structured, and people were therefore classified according to their social group. An individual's identity and actions were determined by the group, and as a result the consequences of person's actions were also decided upon in the group (or social group). The 'self' was understood in terms of how others saw you or what others said about you. In a society that functioned in this way, great value was placed on things such 'as obedience, faithfulness, and loyalty to tradition' (Neyrey 2016a:46-49). 
group, even if you as an individual know the truth to be different. The individual must preserve or keep harmony in the group, and therefore a person's personal opinion does not matter. In an individualistic culture, if a person knows the truth to be different, they will express it (Pilch 2016:23). GenMe even differs here from that of a typical individualistic culture that will present a truth or personal opinion towards others, for GenMe defines truth as 'my truth' or 'truth is individual', meaning highly subjective. For GenMe, the truth or opinion of each individual is therefore important. Your truth is not my truth, and that is acceptable (cf. Crabapple 2015:266; Sweet 2019:141).

In ancient Near Eastern collectivistic cultures, an individual's behaviour or actions were also determined by the in-group, as your actions represented the in-group. How the public saw you is how your in-group was seen. In-groups' views could differ and could therefore be challenged by other groups. It was the individual's responsibility to represent his or her group's view and to keep or gain honour. For these collectivistic cultures, it was viewed as safer to be part of the group or collective (Pilch 2016:23-25). Collectivistic cultures or group-orientated cultures are unmistakably and extensively structured, and every member knows his or her place in this system. The group's (family, clan and nation) behaviour and actions are thus strongly influenced by tradition to indicate what is normative.

According to Malina (2010), individualists believe that:

Single persons are unique and distinct relative to other persons. Collectivists on the other hand believe groups are unique and distinct relative to other groups. The unique and distinct groups to which persons belong through no choice of their own are groups into which a person is born and socialized: parents and family by birth, place by location of the kin group, gender by patriarchal gender roles. Genealogy, geography, and gender serve to define single groups as unique and distinct. It is group features that then define single group members. (p. 19)

Just as GenMe believes in their individualistic nature that every person is unique, a self-uniqueness, every collectivistic group believes that it is unique. The problem is not being unique (whether it is individualistic or collectivistic), but rather what or who is included and excluded because of one's understanding or view.

An important principle in a group-orientated culture is that one needs to follow and learn from one's elder, leader or master; authority, therefore, plays an important role. Boasting about yourself and your status is not acceptable in a grouporientated structure, and such behaviour is open to criticism. What is clear from group-orientated cultures is that they place a high value on authority. An individual bounded by a group (either by family, clan, tribe or nationality) will only place value on the authority of the group if the group's authority is valued as high and important. The role and status of an individual is given by the authority of the group. If God ascribes a specific role or status to a person (e.g. the king or high priest - 1 Samuel 10:1; 16:13; 1 Kings 1:39), it is a demonstration of God's authority over the group or nation of Israel (Neyrey 2016b:80-82). In the Old Testament, a definite example of authoritative power and its enforcement is the Shema (Dt 6:5), where YHWH demands total submissiveness. Authority lies with YHWH (Ex 15:18; Jdg 8:22, 21:25), and any other authority is given by $\mathrm{YHWH}$.

How then would an authoritarian society enforce its focus? According to Malina (2016:10), a number of values are reinforced to accomplish the expectations of authoritarian societies. These values, according to Malina (2016:10), are:

- obedience through total submissiveness to authority

- the tendency to excise power for its own sake

- admiration for the application of physical force

- a high regard for a person's ability to endure pain

- a tendency to be very conventional

- great sensitivity to group pressure

- an anti-introspective personality

- a preference for thinking in terms of either-or, black or white

- a tendency to shift responsibility from the individual onto outside forces - human and non-human - and to project one's unacceptable impulses onto others, particularly 'out-groups'

- a preference for stereotypical thinking.

The differences between collectivistic cultures and individualistic cultures have been discussed, but there is one individualistic trait of collectivistic cultures that tends to bring division and to have a negative impact on the group. Malina (2010:23) explains that in collectivistic cultures, order or rank is exceptionally strong and therefore status in these groups varies. What happens in such groups is that smaller in-groups or individualistic-like behaviour develops between the extremes of the hierarchical ranks and status. This can be viewed as dualistic-like behaviour between members in the same group (family, clan and nation). A typical example is the divide that happens between the elite and the poor. The elite seek more wealth and power. Those who cannot attain or maintain their social status, meaning the lower-ranked in order and status, become the marginalised of society ('the beggars, prostitutes, disinherited sons, familyless widows, orphans or children of those families' [Malina 2010:23]). These marginalised in society become cut off from their collectivistic in-group. Where the collectivistic group is supposed to strengthen the group, these individualistic-like behaviours of smaller sections within the group destroy the harmony, value and strength of a collectivistic group. It is, therefore, a misuse of power and authority.

Reflecting on the question of how the church can be a change agent in the Fourth Industrial Revolution, it is clear that the generation born during this revolution, namely, GenMe, is an individualistic society. If the church is to compare this generation to those of the ancient Near Eastern and Mediterranean societies that lived in biblical times, it is clear that those societies were group-orientated. Wright (2004:363-364) warns that it would be dangerous and irresponsible to say just because ancient people were group-orientated that their moral standard and way of living was ideal or that they should be viewed as the ideal 
Table 1: Translation of Psalm 82.

\begin{tabular}{|c|c|c|c|c|c|}
\hline \multicolumn{3}{|c|}{ Superscription } & \multirow{2}{*}{ 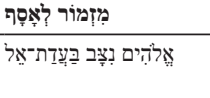 } & \multirow{2}{*}{$\frac{1 a}{B}$} & \multirow{2}{*}{$\begin{array}{l}\text { An Asaph psalm. } .^{12} \\
\text { God takes his stand }{ }^{13} \text { in the } \\
\text { assembly of the gods, }{ }^{14}\end{array}$} \\
\hline 1 & A & 1 & & & \\
\hline & & & 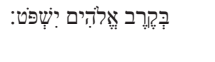 & c & $\begin{array}{l}\text { in the midst of the gods he } \\
\text { renders judgement. } .^{15}\end{array}$ \\
\hline \multirow[t]{10}{*}{ II } & B & 2 & 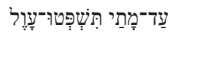 & $2 a$ & $\begin{array}{l}\text { 'How long will you judge/rule } \\
\text { unjustly/dishonestly }\end{array}$ \\
\hline & & & 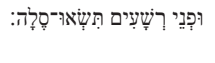 & $b$ & $\begin{array}{l}\text { and lift up the face of the } \\
\text { wicked? Selah }\end{array}$ \\
\hline & & 3 & 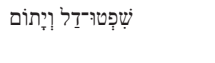 & 3a & $\begin{array}{l}\text { Judge/Save the marginal/poor } \\
\text { and the orphan, }\end{array}$ \\
\hline & & & 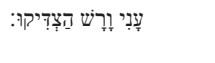 & $b$ & $\begin{array}{l}\text { do justice for the poor and } \\
\text { needy. }\end{array}$ \\
\hline & & 4 & 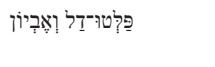 & $4 a$ & $\begin{array}{l}\text { Free the marginal and the } \\
\text { suffering, }\end{array}$ \\
\hline & & & 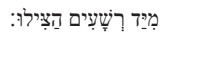 & b & $\begin{array}{l}\text { deliver/save him [them] from the } \\
\text { hand of the wicked'. }\end{array}$ \\
\hline & C & 5 & לא יָדְעוּ וְלא יָבְינוּ & $5 a$ & $\begin{array}{l}\text { They did not know, and they do } \\
\text { not grasp, }\end{array}$ \\
\hline & & & 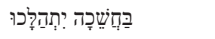 & $\mathrm{b}$ & they wander about in darkness, ${ }^{16}$ \\
\hline & & & 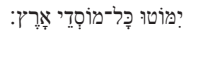 & c & $\begin{array}{l}\text { so all the foundations of the } \\
\text { earth are shaken. }{ }^{77}\end{array}$ \\
\hline & D & 6 & 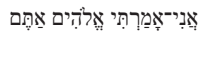 & $6 a$ & $\begin{array}{l}\text { 'Now I declare. Indeed, you are } \\
\text { gods's }^{18}\end{array}$ \\
\hline
\end{tabular}

Table 1 continues $\rightarrow$

12.Psalm 82 is among the Asaphite psalms, relating to Psalms 81 and 83 in its superscription, and the rest of the Asaphite collection in Psalms 73-83. The theme of judgment and justice and that of God or YHWH as a righteous judge recalls the Davidic collection of Psalms 51-72 (cf. Cole 2000:102; Hossfeld \& Zenger 2005:328) For a discussion on the relation between other psalms in Book III of the Psalter and Psalm 82 and further intertextual relations, see Cole (2000:102-109).

13.God takes his stand in this verse, implies something of the hierarchical assembly of gods as seen with the Canaanite and ancient Near Eastern religions. God takes up his position as the head or leading god. See also 1 Kings 22:19; Isaiah 6:1-3; Job 1-2; Psalms 29:1-2, 9-10; and 89:6-8 (Hossfeld \& Zenger 2005:329).

14.The use of אלה is important in this psalm, as stands for YHWH in the Elohistic section of the Psalter (Pss. 42-83). In 1c stands stands for the gods (Tate

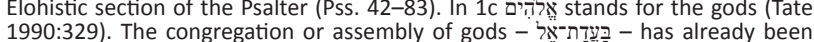
seen in Psalm 74:2 (Cole 2000:102). For a comprehensive description on the use of seen in Psalm 74:2 (Cole 2000:102). For a comprehensive description on the use of Psalm 82 is, who are the gods in verses 1 and 6 ? These gods can be interpreted as
Panse (1990) Psalm 82 is, who are the gods in verses 1 and 6 ? These gods can be interpreted as
divine beings, with reference to Canaanite mythology or other ancient Near divine beings, with reference to Canaanite mythology or other ancient Near court (according to the LXX text of Dt 32:8-9); angels; demoted gods of the nations; divine kings ruling over the nations; tyrannical foreign rulers abusing the subjugated Israel and Judah; or human judges. For further discussion on the topic, see Tsevat (1969-1970:123-137), Anderson (1972:93), Niehr (1987:94-98), Prinsloo (1995:219-228) and Trotter (2012:221-239). The question is further complicated with the intertextual use of Psalm 82:6 in John 10:34-36. For an explanation on the New Testament usa use New Testament usage of Psalm 82:6 in John 10:34-36, see Ackerman (1966:186191) and Neyrey (1989:647-633). In this article the divine council is viewed as those who did not follow YHWH's rule to do justice to the poor and needy and also
supported the wicked; they are viewed as part of Israel's in-group (group supported

15.The verb שפט [judge] appears four times in Psalm 82:1b, 2a, 3a and 8a. The verb is ich in meaning and can be translated with different nuances throughout the psalm (Hossfeld \& Zenger 2005:328). The judgment of God is described in verse 1 and then recalled again in verse 5 . The relation between Psalms 81 and 82 is noticeable when the judgments are disobeyed in 81:12 and 82:2-3. Wickedness must be judged in Psalm 82:7. God must take the responsibility of doing justice in Psalm 82:2 to rectify what the human judges would not do or failed to do. These judges failed to do justice and uphold righteousness (Ps 82:2-4), resembling those in Psalm 73:10. The gods mentioned in Psalm 82 verses $1 \mathrm{~b}$ and $6 \mathrm{a}$ are those who were appointed to judge in Israel but who did not succeed because of their support for the wicked. The for the wicked. The accusation then against these judges is that they did not uphold justice for the poor and needy, as sanctioned by God, by YHWH. The intertextual theme of justice for the poor is clearly seen between Psalms 72 and 82 . In Psalm 72 the responsibility falls upon the ruler of Israel, the king. According to
Cole (2000:103), 'Israel's judges are being asked in Ps 82 to follow the pattern of Cole (2000:103), 'Israel's judges are bein
the just and righteous ruler in Ps 72 '.

16.The חששכה [darkness] in verse 5 should not only be understood as the absence of light, but can also mean Sheol or the underworld. The implication of the imagery is a separation from YHWH, where there is no communication with God in Sheol; therefore they do not understand (Anderson 1969:393-394).

17.In verse 5 the idea that the gods are the ones that are shaken or totter because they wander in darkness is clarified when it is indicated that it is the earth that is shaken. It can then be understood that the earth is responding to the social injustice that took place or that the earth is shaken as a response to God's anger (Segal 2013:388)

18.The phrase אָנִ presents translation difficulties and therefore the most unlikely translation is preferred. The reasoning is firstly that it is a question of who
the speaker is. Tate $(1990: 334)$ argues that $\mathrm{YHWH}$ is the speaker, as it depends on the speaker is. Tate $(1990: 334)$ argues that YHWH is the speaker, as it depends on
how verses 5 and 6 are interpreted. If verse 6 is seen as a continuation of the
TABLE 1 (Continues...): Translation of Psalm 82.

\begin{tabular}{|c|c|c|c|c|c|}
\hline \multicolumn{3}{|c|}{ Superscription } & \multirow{2}{*}{ 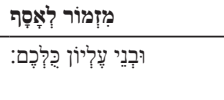 } & \multirow{2}{*}{$\frac{1 a}{b}$} & \multirow{2}{*}{$\begin{array}{l}\text { An Asaph psalm. } \\
\text { and all of you sons of the Most } \\
\text { High. }\end{array}$} \\
\hline & & & & & \\
\hline & & 7 & אָכָן כָָּאָדָם תָתמוּתוּן & $7 a$ & $\begin{array}{l}\text { Nevertheless, you will die like a } \\
\text { human being, }{ }^{19}\end{array}$ \\
\hline & & & 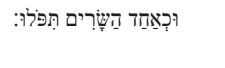 & $b$ & $\begin{array}{l}\text { and like any (one of the) prince } \\
\text { you will fall'. }\end{array}$ \\
\hline \multirow[t]{2}{*}{ III } & $E$ & 8 & 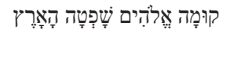 & $8 a$ & $\begin{array}{l}\text { O God, arise, judge/rule the } \\
\text { earth, }\end{array}$ \\
\hline & & & 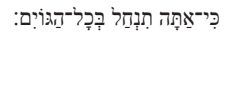 & $b$ & $\begin{array}{l}\text { you, yes, you shall take } \\
\text { possession (for you hold) }{ }^{20} \text { of } \\
\text { your inheritance/estate among } \\
\text { all the nations. }{ }^{21}\end{array}$ \\
\hline
\end{tabular}

society. Yes, there will always be moral values that should be considered, whether a society is individual or group-orientated. Wright (2004:354) would rather argue the case for who determines these values, meaning that the society must reflect that which YHWH wants. In other words, it remains a question of authority. In the next section, insights from Psalm 82 are used to address the issue of authority.

\section{Psalm 82}

Samuel Terrien (2003:588) calls Psalm 82 a 'mini-spectacle, a one minute opera'. ${ }^{22}$ The reason for this is that the imagery in this psalm is descriptive of a theme that is earth-shattering: words of condemnation that lead to the death of the gods and the one God that rules over all so as to ensure that the wicked may come to a fall in the end and that justice may rule.

The translation presented in Table 1 is in concurrence with the majority of modern translations. Textual difficulties and notes are discussed to a limited extent in footnotes.

The contents of the psalm can perhaps be represented best as shown in Table 2.

psalmist evaluation of the gods in verse 5 then $\mathrm{YHWH}$ is not the speaker. This interpretation is not followed by most interpreters. Verse 6 can also be understood as a reflection of a specific time in the council setting, recalling a speech by $\mathrm{YHWH}$ as a reflection of a specific time in the council setting, recalling a speech by YHWH,
rebuking the gods; then YHWH is the speaker. The latter means a probable rebuking the gods; then YHWH is the speaker. The latter means a probable translation for
translations $\mathrm{YHWH}$ will be revoking his former decree. A popular translation is also translations YHWH will be revoking his former decree. A popular translation is also
'I thought'. The problem with this translation is that it seems then that YHWH is 'I thought'. The problem with this translation is that it seems then that YHWH is
rectifying a misconception that he as YHWH held. This interpretation seems unlikely, just as it seems unlikely that the phrase is meant sarcastically (cf. Hossfeld \& Zenger 2005:329; Tate 1990:337-338).

19.The adverb אָ is a strong word and can be translated with force, which expresses a change from that what is expected or assumed, therefore as 'nevertheless', 'truly' or 'surely' (cf. Tate 1990:330)

20.Because of the parallelism in verse 8 , the prefix conjunction is rather translated as a jussive and not an indicative. Therefore נחו is translated as to 'take possession' (cf. Hossfeld \& Zenger 2005:329).

21.The whole psalm is characterised by repetition of words: שפט (vv. 1, 2, 3 and 8);

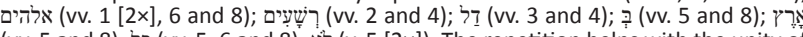
(vv. 5 and 8 ); כל (vv. 5, 6 and 8 ); (v. 5 [2x]). The repetition helps with the unity of the psalms and is already an indication of important themes within the psalm (cf. Prinsloo 1995:222).

22.For Terrien (2003:588), this psalm is like a Greek tragedy that is building up to the universal rule of God. The pace and buildup of the psalm are established in a meter that emphasises the musical phrasing: $3+3$ (v. 1b-4), $3+3+3$ (v. 5), $4+3$ (v. 6$), 3+3$ (v. 7) and $4+4$ (v. 8). There are a few poetic structures to take note of in this psalm: In verses $1 \mathrm{~b}-\mathrm{c}$ there is a chiastic pattern - $\mathrm{a}$ stand/ $\mathrm{b}$ gods/ $\mathrm{b}$ gods / a judgment; T verses 3 and 4; ellipsis appears in verse 3 as well as verse 4, because the article $\pi$ is conspicuous by its absence from the nouns; verses 3 and 4 show a chiastic pattern verses $6 a$ and $6 \mathrm{~b}$ show a parallel structure; verses $7 \mathrm{a}$ and $7 \mathrm{~b}$ show a paralle structure; verses 5 and 8 form an inclusio with the use of אפטלה a For a detailed discussion on the poetic techniques used in Psalm 82 see Prinsloo (1995:219-228) and Strawn (2014:21-46). 
Table 2: Content outline of Psalm 82.

\begin{tabular}{|c|c|c|c|c|c|}
\hline Stanza & Strophe & $\begin{array}{l}\text { Verse } \\
\text { lines }\end{array}$ & Verses & Themes of strophes & $\begin{array}{l}\text { Themes of } \\
\text { stanzas }\end{array}$ \\
\hline \multicolumn{2}{|c|}{ Superscription } & & $1 \mathrm{a}$ & A psalm of Asaph & \\
\hline 1 & A & 1 & $1 b-c$ & The Council of the Gods & The setting \\
\hline \multirow[t]{3}{*}{ II } & B & $2-4$ & $2-4$ & $\begin{array}{l}\text { Accusation and command: The } \\
\text { charge against the gods }\end{array}$ & \multirow{3}{*}{$\begin{array}{l}\text { God's judgement } \\
\text { of the other } \\
\text { gods }\end{array}$} \\
\hline & C & 5 & 5 & $\begin{array}{l}\text { Pronouncement of guilt: The } \\
\text { ignorance and result of the gods' } \\
\text { actions. }\end{array}$ & \\
\hline & D & $6-7$ & $6-7$ & Sentence: The death of the gods & \\
\hline III & E & 8 & 8 & $\begin{array}{l}\text { Petition: God to be judge and } \\
\text { therefore a prayer for peace in } \\
\text { the whole world }\end{array}$ & $\begin{array}{l}\text { Call for God to } \\
\text { judge as the } \\
\text { universal ruler }\end{array}$ \\
\hline
\end{tabular}

The content of Psalm 82 differs from the rest of the Psalms, as God is portrayed as a supreme or upper judge among the council of gods. The outline of Psalm 82 starts with a setting that seems not to be from an earthly realm. It is clear from the contents of the psalm that it has a strong background in Canaanite and ancient Near Eastern mythologies. ${ }^{23}$ Gerstenberger (2001:115) understands the genre of the psalm as part of community worship, where God is the first-person speaker. The mythological background and council of the gods present for Gerstenberger a time where the polytheistic views of Israel were more common, and the monotheistic restrictions were not yet fully developed. Therefore, the possibility of an original earlier dating for the psalm, ${ }^{24}$ before it was incorporated in the Psalter and went through redactions in its final shaping in the Asaph collection, is plausible. In its location in the Asaph collection, it shows links with Deuteronomy 32 on how God in the Deuteronomist theology is interpreted, as well as with Deutero-Isaiah (Is 41:21-24; 43:8-13; 46:1-2), and therefore a post-exilic dating can be argued. In its final redactional shaping, it is declared throughout the psalm that suffering is a result of injustice in the world and that total devotion must be orientated to God's total dominion and justice (especially v. 8 - cf. Gerstenberger 2001:115; Hossfeld \& Zenger 2005:332; Terrien 2003:591).

When it comes to the outline of this psalm, Charney (2017:53-54) notes the importance of the rhetorical situation that is applied in Psalm 82. The speaker addressing the council of the gods is God/YHWH in this psalm (v. 1). The address to the council is from a first-person speaker, and the accusation is in the form of a question (v. 2 [and vv. 3-4]). What follows is a description of the actions that these gods should take towards others (poor and needy); this is explained in a sequence of imperatives. The lack of persuasive strategies indicates that the speaker has the intention to condemn and not to move or change the gods (vv. 2-7) (Charney 2017:53-54). This rhetorical situation supports the idea that a shift in authority is taking place: where judgement was allocated to the gods, now it is only with God (v. 8). It is a reorientation of the group's identity and authoritative values: authority is not settled in the group, but in a single being who is directing the group.

23.For a further discussion on the mythological background and importance of this psalm see Morgenstern (1939:29-126) and O'Callaghan (1953:311-314).

24.Terrien (2003:591) also argues for a possible Bronze Age dating.
The interpretation of Psalm 82 presents its own difficulties and is mostly interpreted from three perspectives. Firstly, the psalm is interpreted as the death of the gods because of the reason that they did not do their duties to establish justice on earth, for the poor and needy, and therefore $\mathrm{YHWH}$ is declared the only true God. This interpretation follows the mythical background presented in the psalm and is a religious-historical interpretation of the psalm. The second point of departure for interpretation is that the psalm uses mythological language to condemn human judges, who may be officials and/or kings, who abuse their position. The psalm is then understood as prophetic social criticism. The third preference in terms of interpretation by scholars is the declaration of the first two interpretations as a false dichotomy. The reason for this declaration is that the focus is on the actions. The critique in verses $2-4$ is in analogue to verses $6-7$, where the actions of the gods are reflected in the actions of the humans on earth. Therefore, the actions described in verses $2-4$, which describe things that are happening on earth (by the human judges), are ascribed to the gods, just as the actions of the gods are reflected in the actions of the human beings. The actions of the human judges (Canaanite officials) who worship and acknowledge their gods take away the divinity of these gods and render them powerless (v. 7). The social critique is then on those who do not take care of the poor and needy. Because of the theological analogue, the sentence on the gods is also a sentence on those on earth who worshipped these gods and did not take care of the poor and needy (Hossfeld \& Zenger 2005:330-331).

For the purpose of this article, the relation between God (YHWH), the council of the gods and human beings as a group is important as they are their own group or in-group. It is noticeable that there is a hierarchical relation between the members in this group. God is the head or supreme god (because of the Canaanite mythological background of a pantheon of gods) amongst the other gods (vv. 1,6 - 'sons of the Most High'). As already discussed above, the members of a group are responsible for each other, and each individual member represents his or her group. In verses $2-4$, accusations are made that members in the group are not ensuring justice for other members in the group, especially the poor and needy, ${ }^{25}$ for whom they are also responsible. Instead, there is a misuse of power in that they follow the wicked, instead of ensuring justice for those who are suffering. This misuse of power, for personal gain or power, is a typical negative in a group-orientated society (as it is also in an individualorientated society).

In verses 3 and 4, the reasoning for the accusation against the gods by God is given. According to Hossfeld and Zenger (2005:333), an important event is happening here. The traditional view of the tasks of an ancient Near Eastern deity is altered in this psalm. In the ancient Near Eastern contexts, typically the responsibility to protect the orphans, widows 25. For a further discussion on the theology of the poor in the Psalms, see Tucker (2003:161-178) and Bremer (2017:101-116). 
and the expelled (or homeless) rested with one individual 'law deity'. In Psalm 82, this responsibility rests with every god (and therefore member in the group), changing the core characteristic of the deities. The second important change is that traditionally in ancient Near Eastern texts, and also in the Old Testament, the responsibility is in relation to who must be protected. Typically it is understood that it is orphans, widows and the homeless (the marginalised in the group), but in Psalm 82 the list of those who are included is much more comprehensive. The characteristic word pairs namely 'widows and orphans' (the 'widows' are missing in Ps 82), and 'the poor and disposed' are presented in new patterns within the psalm so as to present the new social structures for the group to ensure that the 'wicked' will no longer have the power. The normal word pair 'the poor and the miserable' [עני אביון] is separated (cf. v. 3b, 4a). Hossfeld and Zenger (2005; cf. also Tucker 2004:425-439) explains that:

The psalm constructs new pairs of words: 'the marginal (דל) and the orphan', 'the poor and needy (רשר)', 'the marginal (דל (דל) and the suffering', and by the repetition of 'marginal' (דל) establishes its own particular accent. (p. 334)

These new pairs not only include those who are marginalised because of their misfortune - 'the widows and orphans' - but also all of those who are disempowered and now marginalised because of the unjust actions of those who have a higher status, who rule or govern them. The injustice of social systems (political and more) is addressed for the masses. It is now a clear, newly defined value of the group regarding how justice must be performed and who is included. The responsibility to adhere to this is situated not only in a specific individual but in all. The death of the gods is because they did not serve justice to all, and therefore it is proclaimed that if this responsibility is not followed, they lose their function and claims to power. This injustice is considered to be of such importance that the imagery is used, where the injustice shook the foundations of the earth (cf. deClaisséWalford, Jacobson \& LaNeel Tanner 2014:644).

Verse 8 declares God (YHWH) as the only god (as all of the gods will die and be without power - v. 7) and is the only god that can bring justice as ruler over the entire world. According to Goldingay (2007), the petition in verse 8 urges $\mathrm{YHWH}$ not only to stand up in the council of the gods but also to take action in the world. In relation to Deuteronomy 32:8-9, this verse proclaims $\mathrm{YHWH}$ to be what he was declared to be, from the time of the exodus (see also Ps 81:11). The petition in this verse should be understood in relation to the entire Asaph collection and the background of a post-exilic community, where $\mathrm{YHWH}$ must overthrow all of those powers (other nations and their gods, and political powers) who marginalise Israel as a nation. Total authority is established in God (YHWH). In the context of the exile, where it would have been seen that $\mathrm{YHWH}$ and his nation had lost, YHWH now ascends above all these gods and their powers. These gods are no longer viewed as gods, but as mere humans, as they will die like mortals (cf. Hossfeld \& Zenger 2005:335-336).
A new universal group is established, where $\mathrm{YHWH}$ is ruler and judge overall. Authority rests with $\mathrm{YHWH}$, and the core value for this group is the responsibility with everyone to keep justice for all, especially all who are marginalised under misfortune, injustice and misuse of power. ${ }^{26}$ For the church as a change agent, these perspectives on Psalm 82 must be considered. According to Tucker and Grant (2018:226), this value is so vital that it must be understood as the only criterion according to which societies are judged by $\mathrm{YHWH}$. Each person must act according to his or her own responsibility to take care of those described in Psalm 82 as the 'marginalised,' implying anyone who needs it.

\section{The church as a change agent}

In conclusion, the issue of how the church can be an effective change agent in the Fourth Industrial Revolution is considered, taking into account the above findings. It is clear that in the current context of the Fourth Industrial Revolution, constant change is a given. For the church to be effective, it should not only embrace change but also take part in change and the process of change. To do this, the church must be able to identify with the culture that functions mainly as a Fourth Industrial Revolution culture, namely, GenMe. This is a highly individual-orientated society, with a generation that is not only self-absorbed (bordering on narcissism), but in which most have very high sense of self-importance and selfesteem. It is the church's responsibility to help to develop this generation and the next, to show more self-efficacy (capacity to execute behaviours necessary to produce specific performance attainments) and community focus. The community focus is not a group-orientated focus. It has been seen that neither an individual nor a group-orientated focus is necessarily a better focus, but rather, according to Psalm 82, a value-orientated focus. Taking responsibility to take care of others in need and those who suffer injustice is more significant.

The danger for an individual and group-orientated society lies in their understanding of where authority is situated. For the individual-orientated GenMe, authority is situated mainly in themselves and each person's own authority; therefore, personal opinion is valued; whereas for a grouporientated society such as those described in the ancient Near East, authority resides with the group, although misuse of power and status in the group is typical. In Psalm 82, authority resides in totality with YHWH. It is the function of the church to change the focus of the individual or group to realise that authority. One of the problems identified for GenMe is their tendency to develop depression because they do not reach their personal dreams or goals as expected. As a change agent, the church can help with selfefficacy development and, in the process, teach a person to reorientate the self-focus and see that dependence and authority is not in oneself but in YHWH.

26. For deClaissé. Waiford, Ja........................ God of Israel's kingdom have worldwide impact'. The values that are described in Psalm 72 are clearly the values not only in the earthly realm, but also in the Psalm 72 are clearly the values not only in the earthly realm, but also in the
heavenly realm. This is now a core universal value. For a further discussion on the heavenly realm. This is now a core universal value. For a further discussic
understanding of the poor in Psalm 72, see Houston (1999:341-367). 


\section{Acknowledgements Competing interests}

The author declares that he has no financial or personal relationships that may have inappropriately influenced him in writing this research article.

\section{Author's contributions}

L.S. is the sole author of this research article.

\section{Ethical considerations}

This article followed all ethical standards for research without direct contact with human or animal subjects.

\section{Funding information}

This research received no specific grant from any funding agency in the public, commercial or not-for-profit sectors.

\section{Data availability statement}

Data sharing is not applicable to this article as no new data were created or analysed in this study.

\section{Disclaimer}

The views and opinions expressed in this article are those of the author and do not necessarily reflect the official policy or position of any affiliated agency of the author.

\section{References}

Ackerman, J.S., 1966, 'The rabbinic interpretation of Psalm 82 and the Gospel of John John 10:34', The Harvard Theological Review 59(2), 186-191. https://doi. org/10.1017/S0017816000009676

Alloway, T., Runac, R., Qureshi, M. \& Kemp, G., 2014, 'Is Facebook linked to selfishness? Investigating the relationship among social media use, empathy, and narcissism', Social Networking 3(3), 150-158. https://doi.org/10.4236/sn.2014.33020

Anderson, A.A., 1972, Psalms (73-150), The New Century Bible Commentary, William B. Eerdmans, Grand Rapids, MI.

Anderson, F.I., 1969, 'A short note on Psalm 82:5', Biblica 50(3), 393-394.

Bremer, J., 2017, 'The theology of the poor in the Psalter', in W.D. Tucker, Jr. \& W.H. Bellinger, Jr. (eds.), The Psalter as witness. Theology: poetry, and genre, pp. 101-116, Baylor University Press, Waco, TX.

Charney, D.H., 2017, Persuading God: Rhetorical studies of first-person Psalms, Sheffield Phoenix Press, Sheffield.

Cole, R.L., 2000, The shape and message of Book III (Psalms 73-89), Sheffield Academic Press, Sheffield.

Crabapple, M., 2015, Drawing blood, HarperCollins Publishers, Sydney.

Davenport, S.W., Bergman, S.M., Bergman, J.Z. \& Fearrington, M.E., 2014, 'Twitter versus Facebook: Exploring the role of narcissism in the motives and usage of different social media platforms', Computers in Human Behaviour 32, 212-220. http://dx.doi.org/10.1016/j.chb.2013.12.011

deClaissé-Walford, N., Jacobson, R.A. \& LaNeel Tanner, B., 2014, The book of Psalms, The New International Commentary on the Old Testament, William B. Eerdmans, Grand Rapids, MI.

Duhigg, C., 2013, The power of habit: Why we do what we do and how to charge, Random House Books, London.

Elias, N., 2001, The society of individuals, Continuum, New York, NY.

Foroohar, R., 2020, COVID-19 and the generational divide, viewed 13 April 2020, from https://www.ft.com/content/6a880416-66fa-11ea-800d-da70cff6e4d3.

Galloway, S., 2017, The four: The hidden DNA of Amazon, Apple, Facebook, and Google, Penguin, New York, NY.

Gerstenberger, E.S., 2001, Psalms, Part 2, and lamentations, The forms of the Old Testament Literature, vol. XV, William B. Eerdmans, Grand Rapids, MI.

Gleason, N.W. (ed.), 2018, Higher education in the era of the Fourth Industrial Revolution, Palgrave Macmillan, Singapore.
Goldingay, J., 2007, Psalms. Volume 2: Psalms 42-89, Baker Commentary on the Old Testament: Wisdom and Psalms, Baker Academic, Grand Rapids, MI.

Gunia, A., 2020, Millennials aren't taking coronavirus seriously, a top WHO official warns, viewed 13 April 2020, from https://time.com/5807073/millennialscoronavirus-who/.

Harari, Y.N., 2015, Homo Deus: A brief history of tomorrow, Harper Collins Publishers, New York, NY.

Hootsuite, 2020, Digital 2020 global digital overview, viewed 14 May 2020, from https://p.widencdn.net/1zybur/Digital2020Global_Report_en.

Hossfeld, F.-L. \& Zenger, E., 2005, Psalms 2, Hermeneia - Critical and Historical Commentary on the Bible, Fortress Press, Minneapolis, MN.

Houston, W., 1999, 'The king's preferential option for the poor: Rhetoric, ideology and ethics in Psalm 72', Biblical Interpretation 7(4), 341-367. https://doi. org/10.1163/156851599x00272

Johnson, S., 2002, Who moved my cheese?, Vermilion, London.

Kelly, R., 2019, Constructing leadership 4.0: Swarm leadership and the Fourth Industrial Revolution, Palgrave Macmillan, Cham.

Kinnaman, D. \& Lyons, G., 2007, Unchristian: What a new generation really thinks about Christianity ... and why it matters, Bakerbooks, Grand Rapids, MI.

Kinnaman, D. \& Lyons, G., 2016, Good faith: Being a Christian when society thinks you're irrelevant and extreme, Bakerbooks, Grand Rapids, MI.

Kotter, J. \& Rathgeber, H., 2006, Our iceberg is melting, Macmillan, London.

Lasch, C., 1991, The culture of narcissism: American life in an age of diminishing expectations, W.W. Norton \& Company, New York, NY.

Leung, L., 2013, 'Generational differences in content generation in social media: The roles of the gratifications sought and of narcissism', Computer in Human Behavior 29(3), 997-1006. https://doi.org/10.1016/j.chb.2012.12.028

Malina, B.J., 2010, 'Collectivism in Mediterranean culture', in D. Neufeld \& R.E. DeMaris (eds.), Understanding the social world of the New Testament, pp. 17-28, Routledge, London.

Malina, B.J., 2016, 'Authoritarianism', in J.J. Pilch \& B.J. Malina (eds.), Handbook of Biblical social values, 3rd edn., pp. 9-14, Cascade Books, Eugene, OR.

McCain, J.L. \& Campbell, W.K., 2018, 'Narcissism and social media use: A metaanalytic review', Psychology of Popular Media Culture 7(3), 308-327. https://doi. org/10.1037/ppm0000137

Morgenstern, J., 1939, 'The mythological background of Psalm 82', Hebrew Union College Annual 14(1), 29-126.

National Institute for Communicable Diseases, 2020, COVID-19, viewed 29 March 2020, from https://www.nicd.ac.za/diseases-a-z-index/covid-19/.

Neyrey, J.H., 1989, '“I said: You are Gods": Psalm 82:6 and John 10', Journal of Biblical Literature 108(4), 647-663. https://doi.org/10.2307/3267185

Neyrey, J.H., 2016a, 'Dyadism', in J.J. Pilch \& B.J. Malina (eds.), Handbook of Biblical social values, 3rd edn., pp. 46-49, Cascade Books, Eugene, OR.

Neyrey, J.H., 2016b, 'Group orientation', in J.J. Pilch \& B.J. Malina (eds.), Handbook of Biblical social values, 3rd edn., pp. 80-83, Cascade Books, Eugene, OR.

Niehr, H., 1987, 'Götter oder Menschen - eine falsche Alternative: Bemerkungen zu Ps 82', Zeitschrift für die alttestamentliche Wissenschaft 99(1), 94-98.

O'Callaghan, R.T., 1953, 'A note on the Canaanite background of Psalm 82', The Catholic Biblical Quarterly 15(3), 211-314.

Pilch, J.J., 2016, 'Collectivism', in J.J. Pilch \& B.J. Malina (eds.), Handbook of Biblical social values, 3rd edn., pp. 20-25, Cascade Books, Eugene, OR.

Prinsloo, W.S., 1995, 'Psalm 82: Once again, gods or men?', Biblica 76(2), 219-228.

Reid, A.J. \& Thomas, C.N., 2017, 'A case study in smartphone usage and gratification in the age of narcissism', International Journal of Technology and Human Interaction 13(2), 40-56. https://doi.org/10.4018/IJTHI.2017040103

Ryan, F., Bednar, M. \& Sweeder, J., 1999, 'Technology, narcissism, and the moral sense: Implications for instruction', British Journal of Educational Technology 30(2), 115-128. https://doi.org/10.1111/1467-8535.00100

Schwab, K., 2016, The Fourth Industrial Revolution, World Economic Forum, Geneva.

Segal, B.J., 2013, A new psalm: The Psalms as literature, Gefen, Jerusalem.

Stieg, C., 2020, The psychological reasons why Gen X may be taking COVID-19 more seriously than boomers and millennials, viewed 13 April 2020, from https://www. $\mathrm{cnbc}$.com/2020/03/18/psychological-reason-why-gen-x-is-taking-covid-19pnbc.com/2020/03/18/psy

Strawn, B.A., 2014, 'The poetics of Psalm 82: Three critical notes along with a plea for the poetic', Review Biblique 121(1), 21-46.

Sweet, L., 2012, Viral: How social networking is poised to ignite revival, Waterbook Press, Colorado Springs, $\mathrm{CO}$

Sweet, L., 2014, From tablet to table: Where community is found and identity is formed, NavPress, Colorado Springs, CO.

Sweet, L., 2019, Rings of fire, NavPress, Colorado Springs, CO.

Tate, M.E., 1990, Psalms 51-100, Word Biblical Commentary, Nelson Reference \& Electronic, Nashville, TX.

Terrien, S., 2003, The Psalms: Strophic structure and theological commentary, Volume 2 Psalms 73-150, Eerdmans Critical Commentary, William B. Eerdmans, Grand Rapids, MI. 
Trotter, M.J., 2012, 'Death of the אלהים in Psalm 82', Journal of Biblical Literature 131(2), 221-239. https://doi.org/10.2307/23488222

Tsevat, M., 1969-1970, 'God and the gods in assembly: An interpretation of Psalm 82', Hebrew Union College Annual 40(41), 123-137.

Tucker, W.D., Jr., 2003, 'Democratization and the language of the poor in Psalms 2-89', Horizons in Biblical Theology 25(1), 161-178. https://doi.org/10.1163/ $187122003 \times 00123$
Tucker, W.D., Jr., 2004, 'A polysemiotic approach to the poor in the Psalms', Perspectives in Religious Studies 31(4), 425-439.

Tucker, W.D., Jr. \& Grant, J.A., 2018, Psalms, volume 2, New International Version Application Commentary, Zondervan, Grand Rapids, MI.

Twenge, J.M., 2014, Generation Me, rev. edn., Atria, New York, NY.

Wright, C.J.H., 2004, Old Testament ethics for the People of God, InterVarsity Press Academic, Downers, II. 